\title{
Alveolar recruitment improves ventilatory efficiency of the lungs during anesthesia
}

\author{
[Le recrutement alvéolaire améliore l'efficacité ventilatoire des poumons pendant \\ l'anesthésie]
}

Gerardo Tusman MD,${ }^{*}$ Stephan H. Böhm MD,† Fernando Suarez-Sipmann MD, $\ddagger$ Elsio Turchetto MD\$

Purpose: The goal of this study was to analyze the effect of positive end-expiratory pressure (PEEP), with and without a lung recruitment maneuver, on dead space.

Methods: 16 anesthetized patients were sequentially studied in three steps: I) without PEEP (ZEEP), 2) with $5 \mathrm{~cm} \mathrm{H}_{2} \mathrm{O}$ of PEEP and 3) with $5 \mathrm{~cm} \mathrm{H}_{2} \mathrm{O}$ of PEEP after an alveolar recruitment strategy (ARS). Ventilation was maintained constant. The single breath test of $\mathrm{CO}_{2}\left(\mathrm{SBT}-\mathrm{CO}_{2}\right)$, arterial oxygenation, end-expiratory lung volume (EELV) and respiratory compliance were recorded every 30 min.

Results: Physiological dead space to tidal volume decreased after ARS $(0.45 \pm 0.01)$ compared with ZEEP $(0.50 \pm 0.07, P<0.05)$ and PEEP $(0.51 \pm 0.06, P<0.05)$. The elimination of $\mathrm{CO}_{2}$ per breath increased during PEEP $\left(25 \pm 3.3 \mathrm{~mL} \cdot \mathrm{min}^{-1}\right)$ and ARS $(27 \pm$ $\left.3.2 \mathrm{~mL} \cdot \mathrm{min}^{-1}\right)$ compared to ZEEP $\left(23 \pm 2.6 \mathrm{~mL} \cdot \mathrm{min}^{-1}, P<0.05\right)$, although ARS showed larger values than PEEP $(P<0.05)$. Pa-etCO difference was lower after recruitment $(0.9 \pm 0.5 \mathrm{kPa}, P<0.05)$ compared to ZEEP $(\mathrm{I} . \mathrm{I} \pm 0.5 \mathrm{kPa})$ and PEEP $(\mathrm{I} .2 \pm 0.5 \mathrm{kPa})$.

Slope II increased after ARS $(63 \pm 11 \% / \mathrm{L}, P<0.05)$ compared with ZEEP (46 $\pm 7.7 \% / L)$ and PEEP (56 $\pm 10 \% / L)$. Slope III decreased significantly after recruitment $(0.13 \pm 0.07 \mathrm{I} / \mathrm{L}) \mathrm{com}-$ pared with ZEEP $(0.21 \pm 0.1 \mathrm{I} / / \mathrm{L})$ and PEEP $(0.18 \pm 0.10 \mathrm{I} / \mathrm{L})$. The angle between slope II and III decreased only after ARS.

After lung recruitment, $\mathrm{PaO}_{2}$, EELV, and compliance increased significantly compared with ZEEP and PEEP.

Conclusion: Lung recruitment improved the efficiency of ventilation in anesthetized patients.
Objectif : Analyser l'effet de la pression télé-expiratoire positive (PEEP) sur l'espace mort, avec et sans recrutement pulmonaire.

Méthode : Nous avons réalisé une étude séquentielle en trois étapes auprès de 16 patients anesthésiés: I) sans PEEP (ZEEP), 2) avec 5 $\mathrm{cm} \mathrm{H}_{2} \mathrm{O}$ de PEEP et 3) avec $5 \mathrm{~cm} \mathrm{H}_{2} \mathrm{O}$ de PEEP à la suite d'une stratégie de recrutement alvéolaire (SRA). La ventilation a été maintenue constante. L'épreuve de l'apnée inspiratoire du $\mathrm{CO}_{2}$, l'oxygénation artérielle, le volume pulmonaire télé-expiratoire (VPTE) et la compliance respiratoire ont été enregistrées toutes les 30 min.

Résultats : Le rapport espace mort/volume courant a été réduit après la SRA $(0,45 \pm 0,01)$ comparée à la ZEEP $(0,50 \pm 0,07, P<$ $0,05)$ et à la $P E E P(0,51 \pm 0,06, P<0,05)$. L'élimination du $\mathrm{CO}_{2}$ pour chaque respiration a augmenté pendant la PEEP (25 $\pm 3,3$ $\left.\mathrm{mL} \cdot \mathrm{min}^{-1}\right)$ et la SRA $\left(27 \pm 3,2 \mathrm{~mL} \cdot \mathrm{min}^{-1}\right)$ comparées à la ZEEP (23 $\left.\pm 2,6 \mathrm{~mL} \cdot \mathrm{min}^{-1}, P<0,05\right)$, même si la SRA a présenté des valeurs plus élevées que la PEEP $(P<0,05)$. La différence Pa-etCO $\mathrm{C}_{2}$ été plus faible après le recrutement $(0,9 \pm 0,5 \mathrm{kPa}, P<0,05)$ comparé à la ZEEP $(I, I \pm 0,5 \mathrm{kPa})$ et à la $\operatorname{PEEP}(1,2 \pm 0,5 \mathrm{kPa})$. La pente II s'est accentuée après la SRA (63 $\pm 1 / \% / L, P<0,05)$ comparée à la ZEEP $(46 \pm 7,7 \% / L)$ et à la PEEP $(56 \pm 10 \% / L)$. La pente III s'est abaissée significativement après le recrutement $(0,13 \pm 0,07$ I/L) comparé à la ZEEP $(0,21 \pm 0,1 / \mathrm{l} / \mathrm{L})$ et à la $\operatorname{PEEP}(0,18 \pm$ 0,10 I/L). L'angle entre les pentes II et III a diminué seulement après la SRA. Après le recrutement alvéolaire, comparé à la ZEEP et à la $P E E P$, la $\mathrm{PaO}_{2}$, le VPTE et la compliance ont augmenté significativement.

Conclusion : Le recrutement alvéolaire améliore l'efficacité de la ventilation chez les patients anesthésiés.

From the Department of Anesthesiology* and Intensive Care Medicine, $\$$ Hospital Privado de Comunidad, Mar del Plata, Argentina; the Department of Anesthesiology, $†$ University Hospital; Hamburg-Eppendorf, Hamburg, Germany; and the Department of Critical Care Medicine,ł Fundación Jimenez Díaz, Madrid, Spain. Address correspondence to: Dr. Gerardo Tusman, Department of Anesthesiology, Hospital Privado de Comunidad, Mar del Plata,

Argentina. Phone: +54-223-4990099; Fax: +54-223-4990099; E-mail: gtusman@hotmail.com

Accepted for publication February 25, 2003.

Revision accepted April 14, 2004. 
A TELECTASIS observed during general anesthesia causes a decrease in arterial oxygenation, functional residual capacity and respiratory compliance. ${ }^{1-3}$ Lung recruitment maneuvers are defined as ventilatory strategies used for treating these negative effects of lung collapse. ${ }^{4-6}$ The goal of these maneuvers is to open up the collapsed lung areas and keep them open over time. This "open lung condition", i.e. a lung without collapse, represents the best ventilation/perfusion relationship $(\mathrm{V} / \mathrm{Q})$ in a particular lung. ${ }^{7}$

Dead space is defined as "wasted" ventilation and can be studied with the single breath test of $\mathrm{CO}_{2}$ $\left(\mathrm{SBT}-\mathrm{CO}_{2}\right)$, the graphic of exhaled $\mathrm{CO}_{2}$ against tidal volume. The SBT- $\mathrm{CO}_{2}$ is closely related to the matching of pulmonary ventilation and perfusion giving information on both the efficiency of ventilation and $\mathrm{CO}_{2}$ exchange. ${ }^{8-10}$

We hypothesized that a lung recruitment maneuver would reduce dead space. The aim of this work was to study the effect of PEEP, with and without a lung recruitment maneuver, on dead space analyzed with the SBT- $\mathrm{CO}_{2}$.

\section{Methods}

After approval by the local Ethics Committee and after obtaining written informed consent, we prospectively studied sixteen patients undergoing open lower abdominal surgery. We enrolled patients ASA II-III, without smoking history or cardiopulmonary uncompensated diseases.

Anesthesia induction was performed with fentanyl 4 $\mu \mathrm{g} \cdot \mathrm{kg}^{-1}$, thiopental $3 \mathrm{mg} \cdot \mathrm{kg}^{-1}$ and vecuronium 0.08 $\mathrm{mg} \cdot \mathrm{kg}^{-1}$ and maintained with isoflurane and bupivacaine $0.5 \%$ through an epidural catheter inserted at L2-3.

After tracheal intubation with a cuffed endotracheal tube, we ventilated the lungs with a Siemens $900 \mathrm{C}$ ventilator (Siemens-Elema, Solna, Sweden). Air leak around the endotracheal tube was detected by comparing inspired-expired tidal volume (VT) measured proximally in the airway. A volume controlled mode was used with a VT of $8 \mathrm{~mL} \cdot \mathrm{kg}^{-1}$, respiratory rate (RR) between 10 to 15 beats. $\mathrm{min}^{-1}, \mathrm{FIO}_{2}$ of 0.5 , inspiratory time of 0.3 without pause and, initially, without positive end-expiratory pressure (ZEEP). We increased or decreased alveolar ventilation by adjusting $\mathrm{RR}$ to reach an end-tidal $\mathrm{CO}_{2}$ value of $34 \mathrm{mmHg}$ while maintaining VT constant.

Static respiratory compliance was measured dividing VT by the pressure differences between plateau and total PEEP.

End-expiratory lung volume (EELV) was measured by pushing the expiratory pause button of the Servo
900C for six seconds during the inspiratory pause while releasing PEEP from $5 \mathrm{~cm} \mathrm{H}_{2} \mathrm{O}$ to ZEEP. Thus, a volume of gas is expelled until functional residual capacity at ambient pressure is reached. The EELV was then determined by subtracting the average value of the latest three normal expiratory tidal volumes before the maneuver from the volume of gas measured. We recorded this volume continuously in a computer and analyzed it off-line. The return of the expiratory flow curve to baseline at the EELV-maneuver was used for checking air trapping.

Carbon dioxide elimination $\left(\mathrm{VCO}_{2}\right)$ was calculated by multiplying alveolar ventilation and mean alveolar fraction of $\mathrm{CO}_{2}$. Oxygen consumption $\left(\mathrm{VO}_{2}\right)$ was calculated as the product of alveolar ventilation and inspiratory-expiratory $\mathrm{O}_{2}$ difference. The respiratory quotient was calculated dividing $\mathrm{VCO}_{2}$ by $\mathrm{VO}_{2}$.

The SBT- $\mathrm{CO}_{2}$ and its variables are explained in Appendix I, available as Additional Material at www.cja-jca.org.

\section{Protocol}

We maintained the ventilatory, hemodynamic and metabolic states constant during the study. In each patient we studied three periods sequentially:

1. ZEEP: ventilation with zero PEEP.

2. PEEP: ventilation with $5 \mathrm{~cm} \mathrm{H}_{2} \mathrm{O}$ of PEEP.

3. ARS: between point 2 and 3 , we ventilated the lungs for $20 \mathrm{~min}$ without PEEP to reach baseline conditions once again. The ARS is a maneuver assigned to treat pulmonary collapse by reaching the alveolar opening pressure for ten breaths and keeping the lung open with a PEEP level above the lung's closing pressure. ${ }^{5}$ In our patients we assume that the lung opening pressure was $40 \mathrm{~cm} \mathrm{H}_{2} \mathrm{O}$ of peak inspiratory pressure (PIP) and the closing pressure lower than $5 \mathrm{~cm} \mathrm{H}_{2} \mathrm{O} .{ }^{1,4,5}$

The maneuver was performed in pressure control ventilation following sequential steps (Figure 1):

(a) Ventilatory frequency was set to 15 breaths $\min ^{-1}$.

(b) Inspiration/expiration ratio was set at 1:l.

(c) Delta pressure or the pressure difference between PIP and PEEP (PIP/PEEP) was maintained at $20 \mathrm{~cm} \mathrm{H}_{2} \mathrm{O}$.

(d) Airway pressures were increased in steps: $25 / 5$ to $30 / 10$ and then to $35 / 15 \mathrm{~cm} \mathrm{H}_{2} \mathrm{O}$. Each step of pressure was maintained for five breaths.

(e) A final PIP/PEEP step of $40 / 20 \mathrm{~cm} \mathrm{H}_{2} \mathrm{O}$ was reached and maintained for ten breaths.

(f) After the ten breaths, airway pressures were 
TABLE I Dead space data

\begin{tabular}{llll}
\hline Variable & ZEEP & PEEP & ARS \\
\hline VD/VT & $0.50 \pm 0.07$ & $0.51 \pm 0.06$ & $0.45 \pm 0.01^{*} \dagger$ \\
VDAW $(\mathrm{mL})$ & $160 \pm 48$ & $161 \pm 38$ & $137 \pm 32$ \\
VDALV $(\mathrm{mL})$ & $110 \pm 35$ & $113 \pm 30$ & $108 \pm 32$ \\
VDPHYS $(\mathrm{mL})$ & $270 \pm 54$ & $274 \pm 56$ & $246 \pm 50$ \\
VDALV/VTALV & $0.29 \pm 0.05$ & $0.28 \pm 0.06$ & $0.26 \pm 0.04$ \\
VDAW/VT & $0.30 \pm 0.08$ & $0.29 \pm 0.04$ & $0.25 \pm 0.04 \dagger \ddagger$ \\
VTCO $_{2, \text { br }}(\mathrm{mL})$ & $23 \pm 2.6$ & $25 \pm 3.3^{*}$ & $27 \pm 3.2 \dagger \ddagger$ \\
VTALV $(\mathrm{mL})$ & $340 \pm 72$ & $355 \pm 71$ & $373 \pm 68 \dagger \ddagger$ \\
Vol I/VT & $0.22 \pm 0.09$ & $0.21 \pm 0.06$ & $0.18 \pm 0.06$ \\
Vol II/VT & $0.35 \pm 0.05$ & $0.28 \pm 0.05^{*}$ & $0.26 \pm 0.05 \dagger$ \\
Vol III/VT & $0.45 \pm 0.08$ & $0.51 \pm 0.1^{*}$ & $0.57 \pm 0.09 \dagger \ddagger$ \\
Slope II $(\% / \mathrm{L})$ & $46 \pm 7.7$ & $56 \pm 10^{*}$ & $63 \pm 11 \dagger \ddagger$ \\
Slope III/N $\left(\mathrm{L}^{-1}\right)$ & $0.21 \pm 0.11$ & $0.18 \pm 0.10^{*}$ & $0.13 \pm 0.07 \dagger \ddagger$ \\
Angle II/III $\left({ }^{\circ}\right)$ & $127 \pm 2.1$ & $125 \pm 7.7$ & $113 \pm 4 \dagger \ddagger$ \\
\hline
\end{tabular}

PEEP $=$ positive end-expiratory pressure ZEEP $=$ without positive end-expiratory pressure; ARS = alveolar recruitment strategy; $\mathrm{VD} / \mathrm{VT}=$ physiologic dead space to tidal volume; VDAW = airway dead space $(\mathrm{mL}) ; \mathrm{VDALV}=$ alveolar dead space $(\mathrm{mL})$; VDPHYS $=$ physiologic dead space $(\mathrm{mL})$; VDAW $/$ VTALV $=$ alveolar dead space to tidal volume; VDAW $/ \mathrm{VT}=$ airway dead space to tidal volume; $\mathrm{VTCO}_{2, \mathrm{br}}=\mathrm{CO}_{2}$ elimination per breath $(\mathrm{mL})$; VTALV = alveolar tidal volume $(\mathrm{mL}) ; \mathrm{Vol} \mathrm{I} / \mathrm{VT}=$ volume of phase I to tidal volume; Vol II/VT = volume of phase II to tidal volume; Vol III/VT = volume of phase III to tidal volume; slope $\mathrm{II}=$ phase II slope; slope III/ $\mathrm{N}$ = normalized phase II slope divided by the mean alveolar concentration of $\mathrm{CO}_{2}$; angle II/III = angle formed between phases II and III slopes $\left({ }^{\circ}\right)$.

Values are presented as mean \pm SD. A $P$ value lower than 0.05 was considered significant. *PEEP against ZEEP, $P<0.05$; †ARS against ZEEP, $P<0.05$; ¥ARS against PEEP, $P<0.05$.

TABLE II Alveolar ventilation and partial pressures of $\mathrm{CO}_{2}$

\begin{tabular}{llll}
\hline Variable & ZEEP & PEEP & ARS \\
\hline $\mathrm{PaCO}_{2}(\mathrm{kPa})$ & $5.1 \pm 0.4$ & $5.2 \pm 0.6$ & $4.9 \pm 0.5$ \\
etCO $_{2}(\mathrm{kPa})$ & $4.0 \pm 0.3$ & $4.0 \pm 0.4$ & $3.9 \pm 0.2$ \\
$\mathrm{~Pa}-\mathrm{etCO}_{2}(\mathrm{kPa})$ & $1.1 \pm 0.5$ & $1.2 \pm 0.5$ & $0.9 \pm 0.5^{*} \dagger$ \\
$\mathrm{VA}\left(\mathrm{L} \cdot \mathrm{min}^{-1}\right)$ & $3.3 \pm 0.8$ & $3.4 \pm 0.6$ & $3.6 \pm 0.8^{*} \dagger$ \\
\hline
\end{tabular}

$\mathrm{PEEP}=$ positive end-expiratory pressure $; \mathrm{ZEEP}=$ without positive end-expiratory pressure; ARS = alveolar recruitment strategy; $\mathrm{PaCO}_{2}$ $=$ arterial partial pressure of $\mathrm{CO}_{2}(\mathrm{kPa}) ;$ etCO ${ }_{2}=$ end-tidal partial pressure of $\mathrm{CO}_{2}(\mathrm{kPa}) ; \mathrm{Pa}$-etCO $\mathrm{CO}_{2}=$ arterial to end-tidal differences of $\mathrm{CO}_{2}(\mathrm{kPa})$; and $\mathrm{VA}=$ alveolar minute ventilation $\left(\mathrm{L} \cdot \mathrm{min}^{-1}\right) .{ }^{*} \mathrm{ARS}$ against ZEEP, $P<0.05$; †ARS against PEEP, $P<0.05$.

gradually decreased returning to the previous setting at $5 \mathrm{~cm} \mathrm{H}_{2} \mathrm{O}$ of PEEP reassuming a volume controlled ventilation mode.

At the end of each period $(30 \mathrm{~min})$, we recorded SBT- $\mathrm{CO}_{2}$ curves and took blood samples for dead space analysis. Blood specimens were processed and corrected for body temperature within five minutes of extraction by a gas analyzer ABL 510 (Radiometer,
Copenhagen, Denmark). Body temperature was measured with an esophageal thermometer.

Comparison of variables among periods was carried out using analysis of variance performed by INSTAT 2.0 (GraphPad, San Diego, CA, USA). If the variance F-statistic was significant the Student-Newman-Keuls post-test detected significant differences. EELV between PEEP and ARS was evaluated by the Student's $t$ test. Values are reported as mean \pm SD and a $P<0.05$ was considered significant.

\section{Results}

Nine females and seven males, aged 65 to $80 \mathrm{yr}$ (71.2 \pm 4.5 ), with body mass indices between 24 to 30 $(26.8 \pm 2.1)$ undergoing hysterectomies $(n=3)$ and hemicolectomies $(n=13)$ were studied.

Lung recruitment increased dead space variables related to lung efficiency and decreased variables related to inefficiency. PEEP alone did not have same effect on dead space (Table I).

Phase II slopes showed a significant increase with PEEP and ARS although lung recruitment showed the highest values. These steeper slopes were associated with a corresponding decreases in Vol II/VT (Table I).

Normalized phase III slope decreased with PEEP ventilation and showed an additional diminution after ARS. Volume of phase III increased with ARS and PEEP compared with ZEEP. The angle between II-III showed significant differences only after the recruitment maneuver (Table I).

Table II shows partial pressures of $\mathrm{CO}_{2}$ and the alveolar ventilation at constant minute ventilation. $\mathrm{Pa}$ etCO $\mathrm{C}_{2}$ was significantly lower and alveolar ventilation larger after ARS compared with ZEEP and PEEP.

Arterial oxygenation, EELV and respiratory compliance showed a significant increase after lung recruitment compared with ZEEP and PEEP. PEEP without lung recruitment showed compliance values significantly higher than ZEEP but without changes in $\mathrm{PaO}_{2}$ (Figure 2).

Hemodynamic and metabolic variables stayed constant at all times (Table III, available as Additional Material at www.cja-jca.org).

\section{Discussion}

When compared with ZEEP or PEEP, lung recruitment decreased those SBT- $\mathrm{CO}_{2}$ variables which are related to pulmonary inefficiency and increased the ones related to efficiency. The increased efficiency of ventilation was associated with an increase in arterial oxygenation, expiratory lung volume and respiratory compliance, all parameters commonly used as markers of an "open lung condition"., ${ }^{1,5-7}$ 


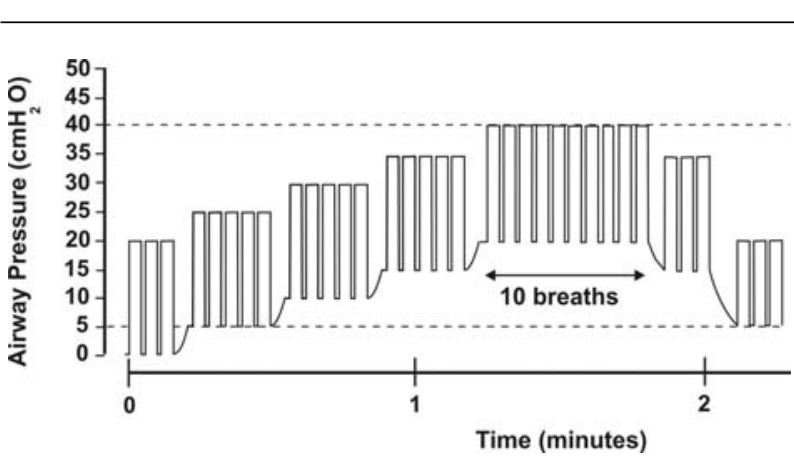

FIGURE 1 Schematic representation of the alveolar recruitment strategy using pressure control ventilation. Rectangles represents tidal volumes set at a pressure difference between peak inspiratory and end-expiratory pressure of $20 \mathrm{~cm} \mathrm{H}_{2} \mathrm{O}$. Airway pressures are increased sequentially in steps from $25 / 5$ to $30 / 10$ and then to $35 / 15 \mathrm{~cm} \mathrm{H}_{2} \mathrm{O}$ every five breaths. A final step of $40 / 20 \mathrm{~cm} \mathrm{H}_{2} \mathrm{O}$ is reached and maintained for ten breaths. After these ten breaths, a progressive decrease to baseline settings is done maintaining a PEEP level of $5 \mathrm{~cm} \mathrm{H}_{2} \mathrm{O}$.

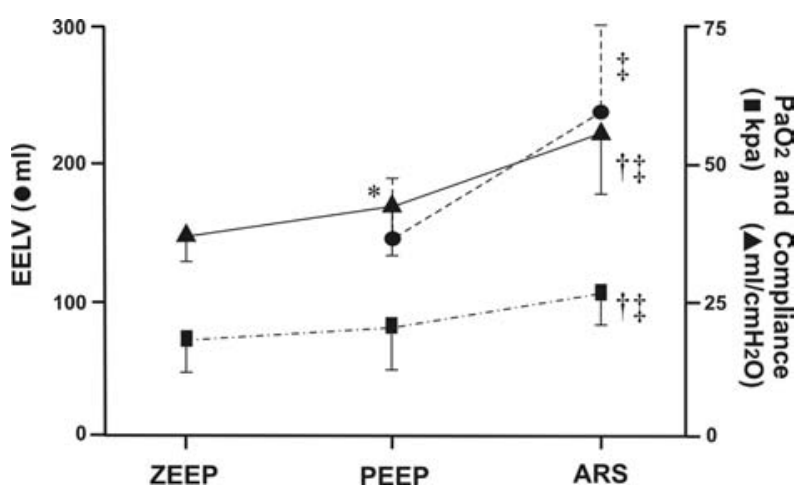

FIGURE $2 \mathrm{PaO}_{2}(\mathrm{kPa})$, Respiratory compliance $\left(\mathrm{mL} \cdot \mathrm{cm}^{-1}\right.$ $\left.\mathrm{H}_{2} \mathrm{O}\right)$, and end-expiratory lung volume (EELV in $\left.\mathrm{mL}\right)$. ZEEP $=$ no PEEP, PEEP $=5 \mathrm{~cm} \mathrm{H}_{2} \mathrm{O}$, and ARS = alveolar recruitment strategy. ${ }^{*}$ PEEP against ZEEP, $P<0.05$; †ARS against ZEEP, $P<$ 0.05 ; †ARS against PEEP, $P<0.05$.

PEEP without recruitment showed an intermediate effect between ZEEP and ARS in all variables studied. In anesthetized patients low levels of PEEP has a contradictory effect on arterial oxygenation ${ }^{5}$ and atelectasis. ${ }^{11}$ Studies results agree in that the recruitment of collapsed airways is the main effect of PEEP without a recruitment maneuver. ${ }^{12,13}$ Atelectasis treatment requires higher airway pressures than the amount of
PEEP commonly used during anesthesia to pop open collapsed alveoli. ${ }^{1,4,5,11}$ The incomplete lung recruitment observed with the use of PEEP alone must be the main explanation for our findings.

In contrast to PEEP alone, lung recruitment maneuver increase both, the cross-sectional area of small airways and the alveolar-capillary area, by reversing airway and acinar collapse respectively. ${ }^{4,1-13}$ This total recruitment or open lung condition ${ }^{7}$ improves the diffusive $\mathrm{CO}_{2}$ transport at the acinar level and could explain the changes observed in the $\mathrm{SBT}-\mathrm{CO}_{2}$.

Increasing $\mathrm{CO}_{2}$ diffusion after the ARS moves the interface between convective-diffusive transport mouthward, thus decreasing the VDAW measured by Fowler's method ${ }^{8}$ (Appendix I, available as Additional Material at www.cja-jca.org).

Lung recruitment was also associated with an improved efficiency in $\mathrm{CO}_{2}$ elimination as expressed by a larger $\mathrm{VTCO}_{2, \text { br }}$ and a lower Pa-etCO $\mathrm{C}_{2}$ at constant $\mathrm{VCO}_{2}$ and ventilator settings. These results indicate that the area of gas exchange increased and V/Q improved.

Differences between PEEP and ARS in the distribution of gas volumes within the lung may have an impact on gas exchange and respiratory compliance. Analyzing EELV and the volumes of phases I-II-III, we observed that the recruitment maneuver re-distributed the VT away from phases I-II towards the volume of phase III (alveolar gas). Compared with ZEEP, PEEP without a recruitment maneuver increased volume of phase III but at the same time, retained some volume within the inefficient parts of the VT (phases I and II).

Changes in the slope of phases II and III at ZEEP could be explained by the co-existence of acini with different time constants due to aging ${ }^{14}$ and partial collapse. Our results resemble those found in asthma and emphysema where both, small airway narrowing and tissue degeneration cause a diffusional resistance to $\mathrm{CO}_{2}$ transport. ${ }^{15,16}$

Total lung recruitment has a positive effect on $\mathrm{CO}_{2}$ diffusion as reflected by the changes observed in volumes and slopes of phases II-III after ARS. On the one hand, we think that an increase in the cross-sectional area caused by airway recruitment could improve the $\mathrm{CO}_{2}$ diffusive transport from alveoli to bronchioli. On the other hand, an increase in the area of gas exchange due to a recruitment of atelectasis improved the diffusive transport from the capillaries to the alveoli (Appendix II, available as Additional Material at www.cja-jca.org).

Some clinical data support our explanation: in children, the multiplication of alveolated airways and pul- 
monary capillaries increases the airway's cross-sectional and gas exchange area with a corresponding decrease in phase III slope. ${ }^{17}$ In contrast, Schwardt et $a l .{ }^{18}$ showed increased phase III slope in emphysema patients with a known reduction in functional zones of the lung.

The design of the study is linear making possible lung volume deteriorations over time. For this reason, we chose to evaluate the recruitment effect in the last term reflecting possibly the worse condition. Future randomized studies are needed to extrapolate our findings into routine clinical practice.

In summary, the ARS improved the efficiency of ventilation in anesthetized patients. Differences observed in the SBT- $\mathrm{CO}_{2}$ between PEEP with and without an lung recruitment maneuver, can be explained by the effectiveness of the treatment of pulmonary collapse.

\section{References}

1 Bendixen HH, Hedley-White J, Chir B, Laver MB. Impaired oxygenation in surgical patients during general anesthesia with controlled ventilation. N Engl J Med 1963; 269: 991-6.

2 Brismar B, Hedenstierna G, Lundquist H, Strandberg A, Svensson L, Tokics L. Pulmonary densities during anesthesia with muscular relaxation - a proposal of atelectasis. Anesthesiology 1985; 62: 422-8.

3 Hedenstierna G, Strandberg A, Brismar B, Lundquist H, Svensson L, Tokics L. Functional residual capacity, thoracoabdominal dimensions, and central blood volume during general anesthesia with muscle paralysis and mechanical ventilation. Anesthesiology 1985, 62: 247-54.

4 Rothen HU, Sporre B, Engberg G, Wegenius G, Hedenstierna $G$. Re-expansion of atelectasis during general anaesthesia: a computed tomography study. $\mathrm{Br}$ J Anaesth 1993; 71: 788-95.

5 Tusman G, Böhm SH, Vazquez de Anda GF, do Campo $J L$, Lachmann B. 'Alveolar recruitment strategy' improves arterial oxygenation during general anaesthesia. Br J Anaesth 1999; 82: 8-13.

6 Amato MB, Barbas CS, Medeiros DM, et al. Effect of a protective-ventilation strategy on mortality in the acute respiratory distress syndrome. N Engl J Med 1998; 338: 347-54.

7 Böhm SH, Vazquez de Anda GF, Lachmann B. The open lung concept. In: Vincent JL (Ed.). Yearbook of Intensive Care and Emergency Medicine, 2nd ed. Berlin, Heidelberg, New York: Springer-Verlag; 1999: 430-40.

8 Fletcher R, Jonson B, Cumming G, Brew J. The concept of deadspace with special reference to the single breath test for carbon dioxide. Br J Anaesth 1981; 53: 77-88.
9 Hofbrand BI. The expiratory capnogram: a measure of ventilation-perfusion inequalities. Thorax 1966; 21 : 518-24.

10 Fletcher R, Jonson B. Deadspace and the single breath test for carbon dioxide during anaesthesia and artificial ventilation. Effects of tidal volume and frequency of respiration. Br J Anaesth 1984; 56: 109-19.

11 Tusman G, Böbm SH, Tempra A, et al. Effects of recruitment maneuver on atelectasis in anesthetized children. Anesthesiology 2003; 98: 14-22.

12 Naureckas ET, Dawson CA, Gerber BS, et al. Airway reopening pressure in isolated rat lungs. J Appl Physiol 1994; 76: 1372-7.

13 Bergman NA, Tien $Y K$. Contribution of the closure of pulmonary units to impaired oxygenation during anesthesia. Anesthesiology 1983; 59: 395-401.

14 Verbeken EK, Cauberghs M, Mertens I, Clement J, Lauweryns JM, Van de Woestijne KP. The senile lung. Comparison with normal and emphysematous lungs. 1. Structural aspects. Chest 1992; 101: 793-9.

15 You B, Peslin R, Duvivier C, Vu VD, Grilliat JP. Expiratory capnography in asthma: evaluation of various shape indices. Eur Respir J 1994; 7: 318-23.

16 Schwardt JD, Neufeld GR, Baumgardner JE, Scherer $P W$. Noninvasive recovery of acinar anatomic information from $\mathrm{CO}_{2}$ expirograms. Ann Biomed Eng 1994; 22: 293-306.

17 Ream RS, Schreiner MS, Neff JD, et al. Volumetric capnography in children. Influence of growth on the alveolar plateau slope. Anesthesiology 1995; 82: 64-73.

18 Schwardt JD, Gobran SR, Neufeld GR, Aukburg SJ, Scherer $P W$. Sensitivity of $\mathrm{CO}_{2}$ washout to changes in acinar structure in a single-path model of lung airways. Ann Biomed Eng 1991; 19: 679-97. 